\title{
ВИКОРИСТАННЯ SOLIDWORKS FLOW SIMULATION ПІД ЧАС МОДЕЛЮВАННЯ ГЕОМЕТРИЧНИХ ФОРМ ДЕТАЛЕЙ КУЗОВІВ АВТОМОБІЛІВ
}

\author{
Ігор Стукалець, к. т. н., Сергій Коробка, к. т. н., Роман Цонинець

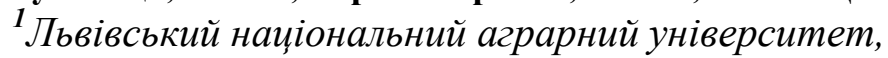 \\ вул. Володимира Великого, 1, м. Дубляни, Львівський р-н, Львівська обл., Україна, \\ e-mail: igorstukalets@gmail.com
}

https://doi.org/10.31734/agroengineering2021.25.127

\begin{abstract}
Стукалець І., Коробка С., Цонинець Р. Використання SolidWorks Flow Simulation під час моделювання геометричних форм деталей кузовів автомобілів

У роботі запропоновано сучасний підхід до моделювання геометричної форми верхнього спойлера-обтічника кабіни вантажного автомобіля за результатами проведеного імітаційного моделювання руху вантажного автомобіля з визначенням коефіцієнта лобового опору з метою зменшення коефіцієнта лобового опору повітря.

Аналіз динаміки автомобіля і наукових праць стосовно аеродинаміки транспортних засобів, а також сучасних методик проведення аеродинамічних досліджень автомобілів і технологій виробництва кузовних та начіпних елементів кузовів автомобілів дав змогу визначити підходи до моделювання геометричних форм елементів кузова транспортних засобів на прикладі верхнього спойлера-обтічника кабіни вантажного автомобіля.

Спойлери кабіни вантажного автомобіля різних геометричних форм змодельовано в CAD-системі SolidWorks 3 використанням поверхневого та твердотілого моделювання. Здійснено імітаційне моделювання руху автомобіля в середовищі модуля гідрогазодинамічного дослідження SolidWorks Flow Simulation, що дало змогу встановити траєкторії руху потоків повітря під час руху автомобіля. На підставі одержаних траєкторій руху повітря, що обтікає автомобіль, визначено контури та напрямні в різних проєкціях та перерізах із наступним використанням їх для геометричного моделювання форми спойлера кабіни складної геометричної форми. На підставі проведених досліджень встановлено значення сили опору повітря на поверхнях автомобіля, побудовано діаграми швидкостей руху повітря та його траєкторій; розраховано значення коефіцієнта лобового опору для кожного 3 варіантів використання спойлерів різних геометричних форм. Визначено та змодельовано геометричну форму спойлера, яка забезпечує найкращі результати з мінімальним значенням коефіцієнта лобового опору.
\end{abstract}

Ключові слова: геометричне моделювання, спойлер, автомобіль, аеродинаміка, SolidWorks Flow Simulation.

Stukalets I., Korobka S., Tsonynets R. Using SolidWorks Flow Simulation for modeling the geometric shapes of car body parts

The paper proposes a modern approach to modeling the geometric shape of the upper spoiler-fairing of the truck cab based on the results of simulation of the truck with the determination of the drag coefficient in order to reduce the drag coefficient. The analysis of car dynamics and scientific works on vehicle aerodynamics, as well as modern methods of aerodynamic research of cars and technologies of production of body and trailer elements of car bodies allowed determining the approaches to modeling geometric shapes of vehicle body elements on the example of upper truck spoiler.

Truck spoilers of various geometric shapes are modeled in the SolidWorks CAD system using surface and solid modeling. Simulation of car movement in the environment of the module of hydrodynamic research SolidWorks Flow Simulation was carried out. It helped to mark the trajectories of air flow during the car movement. Based on the obtained trajectories of the air flow around the car, the contours and guides in different projections and sections are determined, followed by their use for geometric modeling of the shape of the cab spoiler of complex geometric shape. On the basis of the conducted researches, the value of force of the air resistance on surfaces of the car is established, the diagrams of speeds of the air movement and its trajectories are constructed; the value of the drag coefficient for each of the options for using spoilers of different geometric shapes is calculated. The geometric shape of the spoiler, which provides the best results with the minimum value of the drag coefficient, is determined and modeled.

Key words: geometric modeling, spoiler, car, aerodynamics, SolidWorks Flow Simulation.

Постановка проблеми. У сучасних умовах значна частина вантажообігу між містами і краї- нами забезпечується автопоїздами та вантажними автомобілями. Актуальною проблемою для ван- 
тажних автомобілів є проблема зниження витрати палива, яка зумовлена великим значенням коефіцієнта лобового опору вантажних автомобілів. Чим вище значення коефіцієнта лобового опору, тим більша потужність двигуна витрачається на подолання сили лобового опору - це призводить до зростання витрати палива і скорочення пробігу автомобіля на одній заправці.

Якщо вантажні автомобілі в містах пересуваються відносно повільно, то на магістралях їхня швидкість наближається до швидкості легкових автомобілів. Тому зниження аеродинамічного опору є важливим завданням. Порівняно з легковими автомобілями вантажні мають значно більший поперечний переріз (мидель) і менш плавні обриси. Це зумовлено особливостями їхнього призначення й використання.

Під час створення універсального вантажного автомобіля намагаються отримати якомога більший об'єм для розміщення вантажу за мінімальної площі, займаної автомобілем на дорозі, а оскільки частина цієї площі припадає на двигун і кабіну, то відповідно кузов виходить високим (мається на увазі саме вантажний кузов, закритий тентом або обмежений жорсткими стінками, рис. 1). Таким чином, якщо одним зі способів зниження аеродинамічного опору легкового автомобіля $\epsilon$ зменшення його поперечного перерізу, передусім висоти, то для вантажного автомобіля цей шлях виключається.

Можливості поліпшення аеродинаміки вантажного автомобіля, призначеного для руху 3 великою швидкістю, обмежені оптимізацією кузовних деталей і застосуванням різноманітних накладних елементів [4-8; 14].

Одним iз таких накладних елементів $\epsilon$ верхній спойлер-обтічник кабіни (далі - спойлер), обгрунтування геометричної форми якого відіграє важливу роль в ефективності використання його 3 метою зменшення коефіцієнта лобового опору повітря, а також паливної економічності автомобіля.

Аналіз останніх досліджень і публікацій. Під час руху автомобіля важливою складовою сил, які діють на нього, є сила опору повітря $P_{w}$, яка складається зі сили тиску зустрічного потоку повітря, сили, створюваної розрядженням за автомобілем, і сили тертя повітря об поверхню автомобіля. Значення сили опору повітря, яка залежить від лобової площі автомобіля, його форми, швидкості руху і щільності повітря, визначається за формулою

$$
P_{w}=F_{w} \cdot K_{w} \cdot V^{2},
$$

де $F_{w}$ - площа проєкції автомобіля на площину, перпендикулярну до його поздовжньої осі (лобова площа автомобіля), м²; $K_{W}-$ коефіцієнт опору повітря, що залежить від форми автомобіля, якості обробки його поверхні і атмосферних умов, кг $/ \mathrm{M}^{3}$; $V$ - швидкість руху автомобіля.

Значення коефіцієнта опору повітря визначається експериментально продуванням автомобіля або його макета в аеродинамічній трубі. Визначити точне значення лобової площі автомобіля досить важко, оскільки для цього потрібно здійснити вимірювання контурів автомобіля i викреслити його зовнішній контур або мати електронну модель автомобіля (комп'ютерне тривимірне представлення в одній зі сучасних систем геометричного моделювання об'єктів проєктування) [4; 6]. Тому для визначення площі, як правило, користуються наближеними формулами, a саме:

$$
\begin{gathered}
\text { - для вантажних автомобілів } \\
F_{w}=B \cdot H_{a}, \mathrm{~m}^{2} ; \\
\text { - для легкових автомобілів } \\
F_{w}=0,78 B_{a} \cdot H_{a}, \mathrm{~m}^{2},
\end{gathered}
$$

де $B$ - колія автомобіля, м; $B_{a}-$ найбільша ширина автомобіля, м; $H_{a}-$ найбільша висота автомобіля, м.

Ефективним шляхом підвищення паливної економічності автомобілів $\epsilon$ зменшення їхнього аеродинамічного опору [4-8; 14]. Лобовий опір кабіни та кузова-фургона (напівпричепа) становить близько $20 \%$ частки аеродинамічного опору автомобіля.

Сьогодні для зменшення лобового опору вантажного автомобіля використовують різноманітні аеродинамічні конструкції, які не $є$ новинкою в сучасному вантажному автомобілебудуванні.

Кабіни вантажних автомобілів часто мають безкапотне компонування, тобто передня стінка кабіни в нижній частині розташована майже вертикально, а у верхній - із деяким нахилом назад. Передня стінка кузова-фургона вертикальна, плоска, істотно виступає вгору над дахом кабіни. Ширина цієї стінки більша за ширину кабіни. Особливо в разі безкапотного компонування під час руху потік повітря піднімається лобовою частиною кабіни, утворює завихрення i зону зниженого тиску над іiі дахом, потім наштовхується на передню стінку кузова, на якій створюється підвищений тиск, піднімається над дахом кузова, де так само, як над дахом кабіни, утворюються вихори і зона розрідження. Великий 
вплив на формування процесу обтікання повітрям вантажного автомобіля має розмір зазорів між кабіною і кузовом-фургоном [8; 14]. Схема обтікання повітрям вантажного автомобіля 3 кузовомфургоном показана на рис. 1.

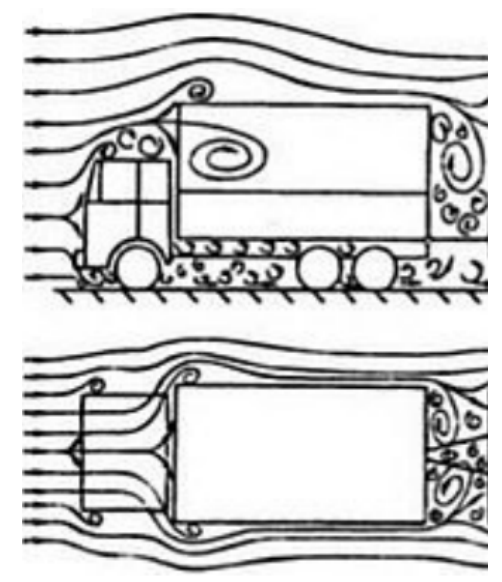

Рис. 1. Схема обтікання зустрічним потоком повітря вантажного автомобіля з кузовом-фургоном

Fig. 1. The scheme of flow around the oncoming air flow of a truck with a van body

Розподіл тиску по кузову вантажного автомобіля з кузовом-фургоном за умови симетричного обтікання потоком повітря показано на рис. 2. Видно, що передня стінка вантажного кузова значною мірою формує й опір форми та індуктивний опір автомобіля [4; 14].

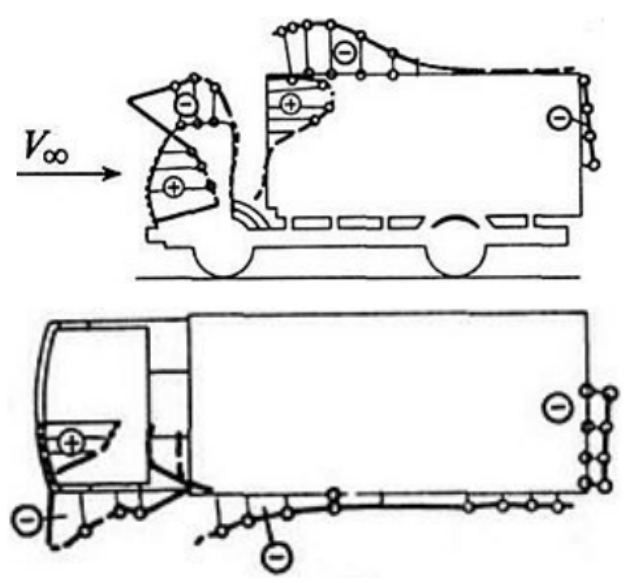

Рис. 2. Розподіл тиску по поверхні вантажного автомобіля

Fig. 2. Pressure distribution on the truck surface

Ці недоліки можна виправити, наприклад, встановленням над дахом кабіни похилого дашка, який «піднімає» потік повітря і скеровує його поверх кузова, це зменшує надлишковий тиск на передню стінку кузова і розрідження на його даху. Зрозуміло, що це знижує загальний аеродинамічний опір автомобіля, і застосування подібного найпростішого аеродинамічного пристрою може зменшити силу опору.

Спойлер-обтічник кабіни - кузовна деталь кабіни комерційних і вантажних автомобілів; декоративна деталь обтічної форми, що забезпечує зниження коефіцієнта аеродинамічного опору кабіни транспортного засобу.

Серед верхніх лобових спойлерів-обтічників масове застосування знайшли обтічники щитового типу. Кривизна їхньої лобової поверхні буває різною, форма також (рис. 3).

Щоб забезпечити максимальну ефективність використання спойлера, його ширину, як правило, вибирають рівною ширині кабіни. За плоского екрана практично весь потік, що йде над кабіною, скеровується на дах кузова-фургона, забезпечуючи так зване верхнє обтікання. За умови повітряного потоку по плоскому щиту, особливо в його нижній частині, виникають зони зриву приграничного шару, що призводить до утворення турбулентного потоку i зниження ефективності використання спойлера. Більш ефективні, хоча й більш складні у виготовленні опуклі щитові спойлери. Їхні лобові поверхні можуть бути циліндричними, еліптичними, параболічними, сферичними. $€$ й більш складні, розраховані на безвідривне обтікання повітряним потоком. Однак на практиці найчастіше застосовують циліндричні щитові спойлери двох типів: спойлери, в яких твірна циліндричної поверхні перпендикулярна (рис. 3, б) до центральної поздовжньої площини автомобіля, і спойлери, в яких вона паралельна (рис. 3, e) до цієї площини. Опуклі циліндричні спойлери першого типу встановлюються, як правило, під кутом до даху кабіни і мають рівну 3 нею ширину. Повітряний потік прямує таким спойлером в основному на дах кузова. Щитові спойлери 3 увігнутим екраном поділяються на два типи: спойлери, в яких твірна увігнутої поверхні або перпендикулярна поздовжній площині автомобіля, або паралельна до цієї площини. Спойлери першого типу (рис. 3, ) прості за конструкцією, однак мають порівняно низьку ефективність: рухаючись по увігнутій поверхні, повітряний потік закручується i «підкидається» вгору, над верхньою кромкою обтічника. Спойлери другого типу (рис. $3, e$ ) особливо ефективні за великих відстаней між кабіною вантажівки та передньою стінкою кузовафургона або напівпричепа, оскільки в цьому разі вдається сконцентрувати повітряний потік, що йде 
над кабіною, в один спрямований струмінь, уникнувши його розтікання по лобовій поверхні щита. За такої умови істотно зростає кінетична енергія повітряного потоку, що скидається на дах кузова за великих відстаней між ним і кабіною (близько 1,5-2,0 м), через що ефективність звичайних спойлерів-обтічників знижується. Слід зазначити, що кут нахилу увігнутого обтічника може бути меншим, ніж в інших щитових спойлерів кабін, що додатково знижує лобовий опір самого спойлера.

Спойлери другого типу (рис. 3, б) встановлюють майже вертикально відносно даху кабіни, і основна частина повітряного потоку, що йде над кабіною тягача, спрямовується на бічні стінки кузова (так зване бічне обтікання). Ще більш ефективні щитові спойлери, що мають кривизну у двох площинах (рис. 3, г). Такий обтічник скеровує повітряний потік, що йде над кабіною, як на дах, так і на бічні поверхні кузова.

Окрім вищезгаданих форм верхніх спойлерівобтічників кабін, широкого використання набули об'ємні спойлери. Якщо щитовий спойлер-обтічник $\epsilon$ універсальним, то об'ємний здебільшого проєктують для конкретного автотранспортного засобу. Об'ємний спойлер скеровує потік повітря, що набігає на лобову частину автомобіля, вгору на дах кузова-фургона, а частину - на бічні поверхні фургона. Такі спойлери $є$ досить ефективними, однак складнішими у виготовленні, а також надають ефектності транспортному засобу, динамічності й естетичної привабливості [8; 14].
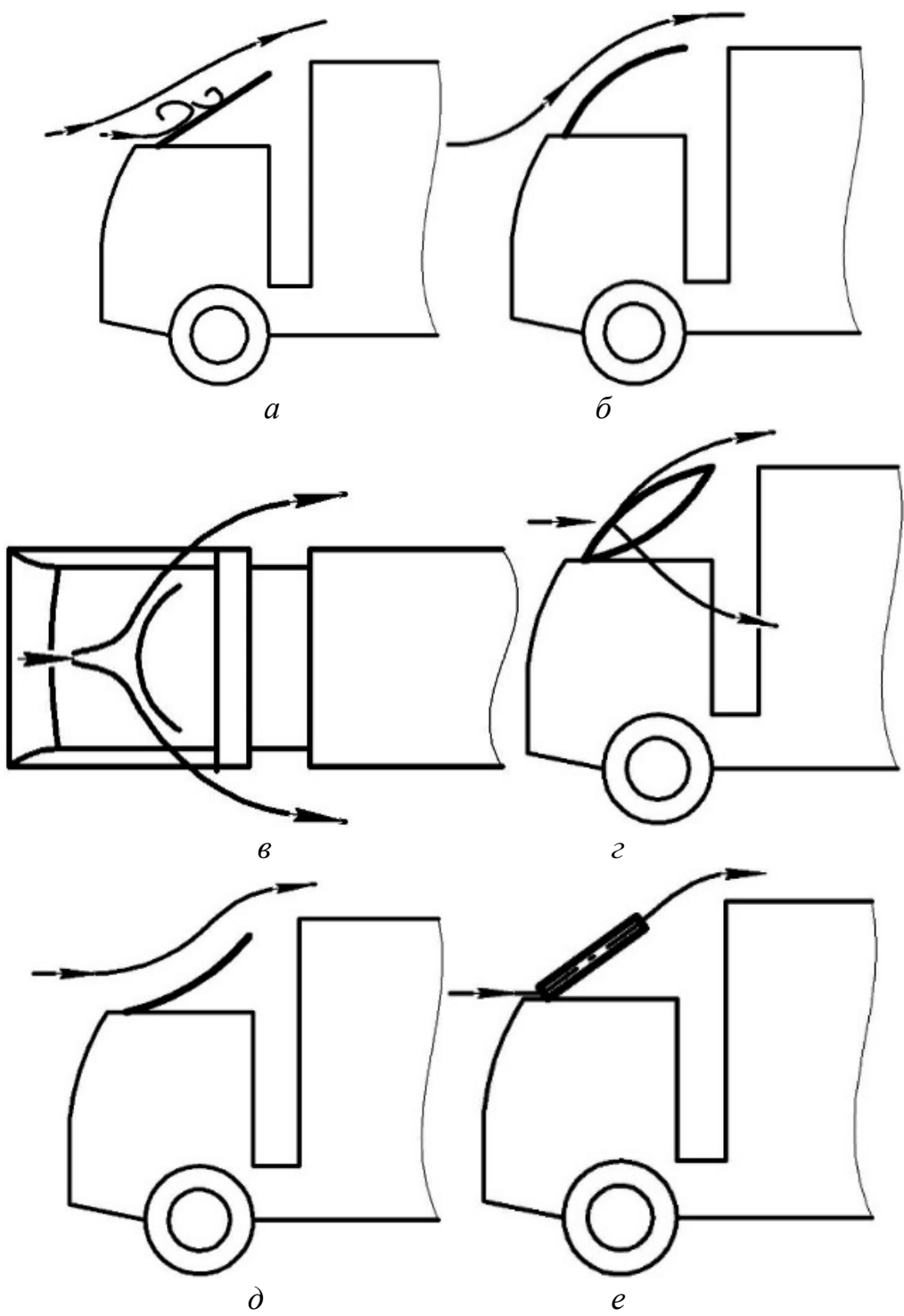

Рис. 3. Форми лобових поверхонь щитових спойлерів-обтічників:

$a$ - плоска; $\sigma$, в - опуклі циліндричні; 2 - двоопуклі; $\partial, e-$ увігнуті циліндричні

Fig. 3. Forms of frontal panel spoilers: $a$ - flat; $\sigma, \varepsilon-$ convex cylindrical; 2 - biconvex; $\partial, e-$ concave cylindrical 
Спойлер-обтічник кабіни виконує декілька функцій:

- зниження сили лобового опору (зниження коефіцієнта аеродинамічного опору автомобіля) - це сприяє поліпшенню динамічних якостей i керованості транспортного засобу, зниженню рівня зовнішнього та внутрішнього шуму і вібрацій кабіни, продовженню ресурсу шин і скороченню навантажень на деякі вузли (у тому числі зниженню інтенсивності зносу даху фургона або тенту);

- економія палива - до 5-15\% залежно від конструкції й класу автомобіля з відповідним скороченням викидів (підвищення екологічних якостей);

- поліпшення естетики автомобіля (дизайн його екстер'єру).

Обтічники кабіни виготовляють із різних матеріалів:

- $\quad$ сталь - це штатні штамповані обтічники кабіни;

- алюміній - полегшені верхні обтічники і козирки;

- склопластик - усі типи обтічників, але найчастіше зі склопластику товщиною до 5 мм формуються верхні обтічники кабін;

- пластик АБС - верхні обтічники, дашки й деякі інші деталі.

Монтаж спойлерів кабіни може виконуватися декількома способами:

- нарізевими кріпильними елементами (болтами, гвинтами) в штатні отвори в деталях кабіни;

- пластиковими заклепками або пістонами в штатні отвори в деталях кабіни;

- нарізевими кріпленнями або заклепками/пістонами зі свердлінням нових отворів;

- за допомогою затискачів, які не потребують свердління.

Дуже часто на практиці встановленням спойлерів зазвичай покращують аеродинамічні характеристики автомобілів, але ефективність їх використання незначна, оскільки виготовлені вони без урахування особливостей геометричної форми конкретної моделі та геометричних характеристик фургона, а враховують лише загальні габаритні та монтажні розміри автомобіля та не перекривають зон фургона, які сприймають велику частину зустрічного потоку повітря.

Виробники об'ємних спойлерів керуються передовсім естетичними міркуваннями під час їх виготовлення, оскільки для визначення ефективності їх використання необхідно здійснювати аеродинамічні дослідження, що вимагають значних фінансових вкладень або залучення фахівців та використання спеціалізованого програмного забезпечення.

Значною проблемою у визначенні ефективності використання спойлерів різних геометричних форм $є$ складність, а часто й неможливість проведення грунтовних досліджень. Адже такі дослідження можуть здійснюватися за умов використання аеродинамічної труби, що є надзвичайно дороговартісним процесом, або за допомогою імітаційного моделювання руху автомобіля в повітряному потоці, що вимагає кваліфікованої інженерної підготовки фахівця та складного спеціалізованого програмного забезпечення.

Постановка завдання. Метою дослідження було зменшення коефіцієнта лобового опору автомобіля завдяки створенню геометричної форми спойлера кабіни автомобіля на підставі проведеного газодинамічного дослідження аеродинаміки руху.

У роботі були поставлені такі завдання:

- проаналізувати аеродинаміку вантажного автомобіля 3 кузовом-фургоном та вплив встановлення додаткових накладних елементів кузова на зменшення лобового опору повітря під час руху;

- здійснити в середовищі SolidWorks Flow Simulation імітаційне моделювання руху автомобіля без спойлера кабіни, визначити траєкторії руху повітря, обчислити коефіцієнт лобового опору;

- здійснити в середовищі SolidWorks Flow Simulation імітаційне моделювання руху автомобіля зі спойлерами кабіни різних типових геометричних форм, визначити коефіцієнт лобового опору;

- виконати моделювання геометричної форми спойлера за результатами аеродинамічного дослідження руху автомобіля;

- здійснити моделювання руху вантажного автомобіля та обчислити коефіцієнт лобового опору 3 використанням запропонованої моделі спойлера, порівняти результати 3 попередніми та визначити ефективність використання запропонованої геометричної форми спойлера.

Виклад основного матеріалу. За об’єкт дослідження прийнято типове та найбільш розповсюджене на практиці безкапотне компонування вантажного автомобіля, на шасі якого встановлено кузов-фургон, габаритні розміри якого за висотою 
та шириною перевищують габаритні розміри кабіни автомобіля.

За геометричну модель автомобіля прийнято модель вантажних автомобілів типового безкапотного компонування вантажопідйомністю до 5 т поширених в Україні моделей, які близькі за габаритними розмірами: Mercedes-Benz Atego 815, MAN TGL, MAN L2000, MA3 4371, Hyundai HD78, Mitsubishi Fuso, Volvo FL 609, Iveco Eurocargo 80 E 17.

Для одержання точних результатів необхідно мати в наявності твердотілу тривимірну модель автомобіля, яка точно відтворює зовнішню геометрію автомобіля. Для цього було створено твердотілу модель вантажного автомобіля в масштабі 1:1 3 використанням можливостей поверхневого та твердотілого моделювання системи автоматизованого проєктування SolidWorks (рис. 4). Дослідження аеродинаміки автомобіля здійснено в середовищі Flow Simulation, що входить до програмного пакета SolidWorks.

Симуляцію руху автомобіля здійснювали за таких початкових параметрів середовища:

- $\quad$ атмосферний тиск - 101325 Па;

- $\quad$ температура повітря - 293,2 K;

- щільність повітря - 1,21 кг/ $\mathrm{M}^{3}$;

- швидкість $-25 \mathrm{~m} / \mathrm{c}$.

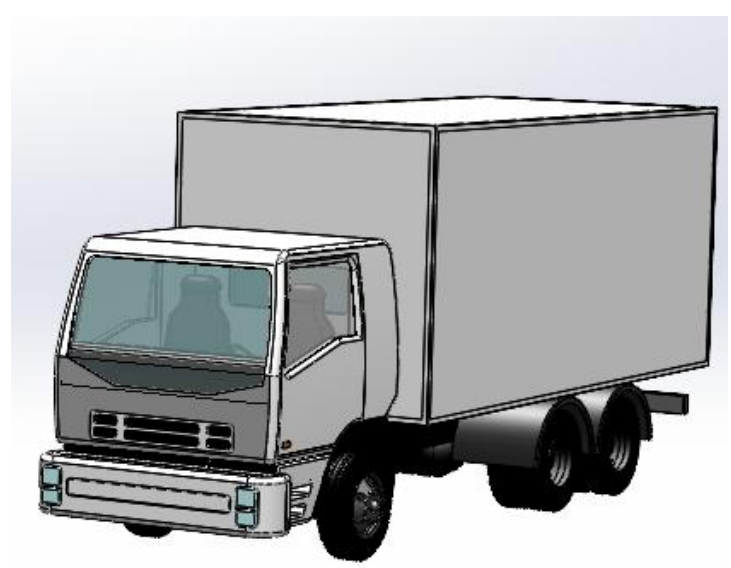

Рис. 4. Твердотіла тривимірна модель вантажного автомобіля

Fig. 4. Solid three-dimensional model of a truck

Основним кількісним результатом дослідження $є$ сила лобового опору, яка присутня у всіх тягово-швидкісних розрахунках та впливає на швидкість і паливну економічність. В аеродинаміці для порівняння автомобілів використовують коефіцієнт аеродинамічного опору $C_{x}-$ безрозмірний коефіцієнт, що характеризує сили лобового опору до швидкості та площі попе- речного перерізу автомобіля. Коефіцієнт лобового опору розраховують за формулою

$$
C_{x}=\frac{2 F_{\pi}}{\rho_{n} \cdot A \cdot V^{2}},
$$

де $F_{\text {л }}$ - сила лобового опору, $\mathrm{H} ; \rho_{\text {п }}-$ щільність повітря, 1,21 кг $/ \mathrm{m}^{3} ; A$ - лобова площа автомобіля (мидель), 9,07 м²; $V$ - швидкість автомобіля, $25 \mathrm{~m} / \mathrm{c}$.

На відміну від класичного методу визначення лобової площі автомобіля, коли вона розраховується за наближеними формулами, у роботі лобову площу автомобіля визначено за допомогою проєктування автомобіля на площину, перпендикулярну до поздовжньої площини автомобіля (рис. 5) у середовищі SolidWorks [1-3; 5; 9-13; 15]. Для всіх випадків використання спойлерів різних геометричних форм лобова площа автомобіля становила $A=9,07 \mathrm{~m}^{2}$.

Як параметр у середовищі SolidWorks Flow Simulation обрано силу лобового опору $F_{\text {л, на }}$ підставі значень якої пізніше обчислено коефіцієнт лобового опору $C_{x}$ вантажного автомобіля для варіантів використання спойлерів різних геометричних форм.

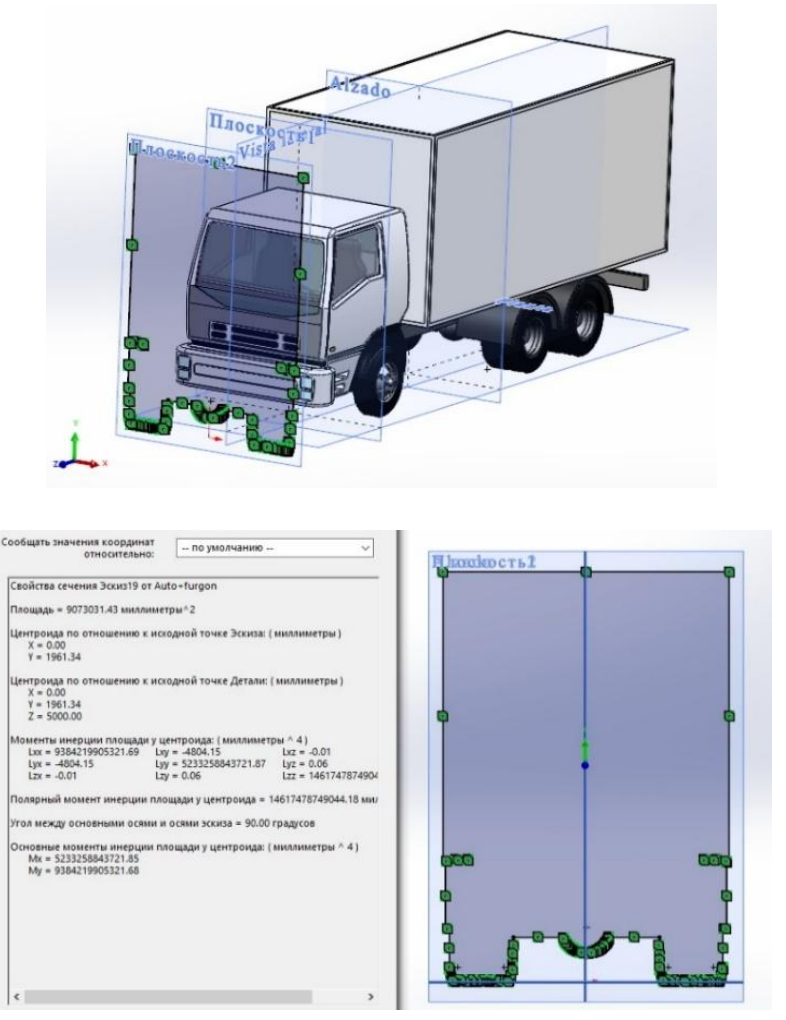

Рис. 5. Визначення лобової площі автомобіля

Fig. 5. Determination the frontal area of the car 
За результатами проведеного імітаційного моделювання руху автомобіля 3 використанням спойлерів різних геометричних форм встановлено значення коефіцієнта лобового опору $C_{x}$. Окрім коефіцієнта лобового опору, система дає змогу також визначити тиск на поверхні автомобіля, величину акустичних шумів, зони турбулентності, повну картину швидкостей потоку повітря в зоні руху автомобіля та низку інших важливих показників [1-3; 5; 9-13; 15].

Результати моделювання руху автомобіля без спойлера. За результатами моделювання руху автомобіля без спойлера встановлено, що максимальне значення опору тиску набігаючого повітря припадає на верхню частину передньої стінки кузова-фургона та розподіляється у вигляді смуги по всій іiі ширині (рис. 6). Крім того, частина повітря, пройшовши шлях над кабіною, вдаряючись до стінки фургона, спрямовується вниз - у простір між кабіною та фургоном, що негативно позначається на аеродинаміці автомобіля в цілому (рис. 7).

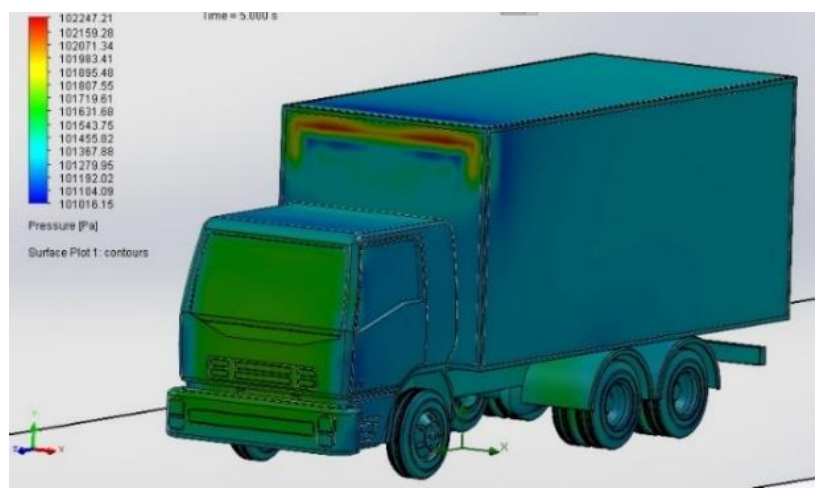

Рис. 6. Діаграма опору тиску

Fig. 6. Diagram of pressure resistance

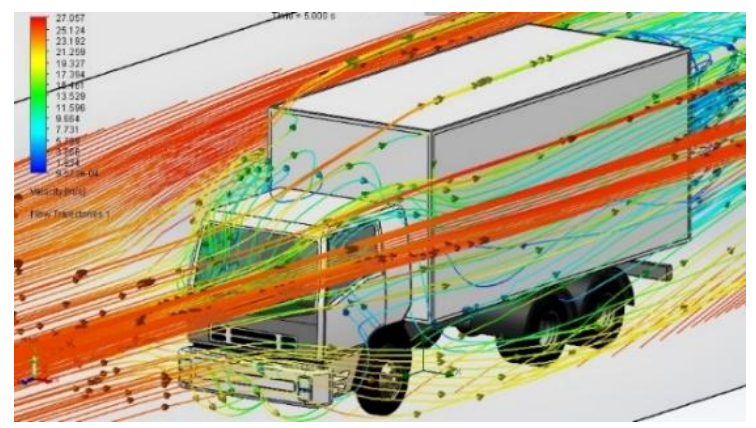

Рис. 8. Зона завихрення над кабіною водія

Fig. 8. Swirl zone above the driver's cab
За умови збільшення деталізації діаграми швидкостей руху повітря (рис. 8) видно, що над кабіною $є$ зони завихрення і турбулентності, що спричинює виникнення додаткового джерела шуму над кабіною водія (44,9 дБ), а це негативно впливає на ергономіку автомобіля та стан водія під час керування транспортним засобом (рис. 9).

Встановлено значення сили лобового опору $F_{\mathrm{I}}=2540 \mathrm{H}$.

Значення коефіцієнта лобового опору $C_{x}$, розрахованого в разі руху автомобіля без використання спойлера, становить

$$
C_{x}=\frac{2 \cdot 2540}{1,21 \cdot 9,07 \cdot 25^{2}}=0,74 .
$$

Наведені вище результати підтверджують загальні теоретичні та експериментальні дослідження, пов'язані з вивченням аеродинаміки вантажних автомобілів, та вказують на необхідність використання спойлерів кабін, а також необхідність наукового підходу до обгрунтування їх геометричної форми.

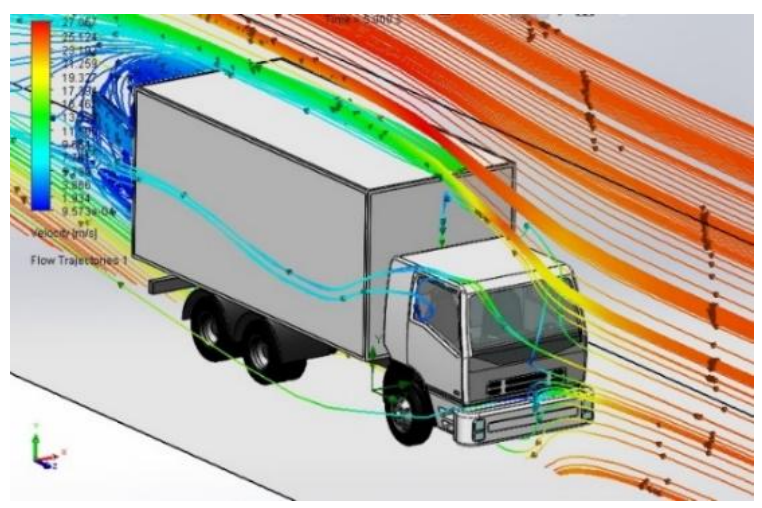

Рис. 7. Діаграма швидкостей руху повітря Fig. 7. Diagram of air velocities

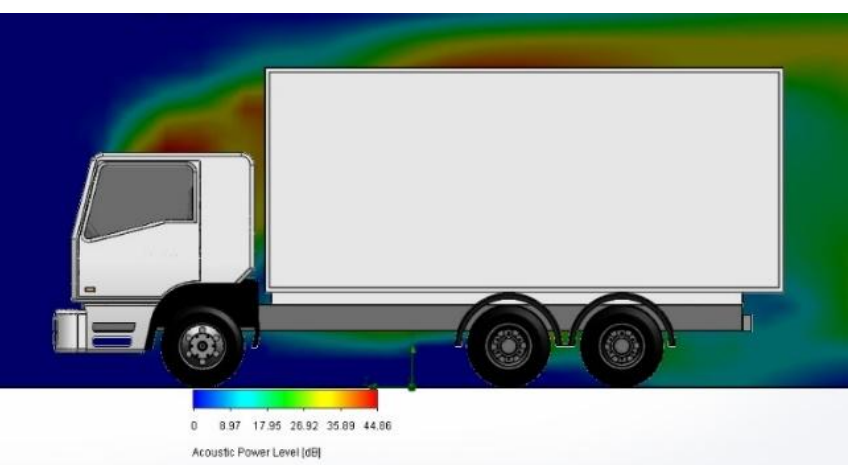

Рис. 9. Діаграма акустичного шуму

Fig. 9. Acoustic level plot 
Результати моделювання руху автомобіля 3 увігнутим спойлером. Увігнутий спойлер має форму прямого кругового циліндра, вісь якого перпендикулярна до центральної поздовжньої площини автомобіля (рис. 10). Ширина спойлера рівна ширині кабіни, бічні стінки - прямі. Визначено значення сили лобового опору $F_{\mathrm{J}}=2392 \mathrm{H}$.

Як видно 3 рис. 11, опір тиску набігаючого повітря, на відміну від попереднього випадку, зосереджено у верхніх кутах передньої стінки фургона, а максимальне значення опору тиску $\epsilon$ нижчим. Через наявність зони фургона, яка не охоплюється спойлером, частина потоку повітря знову ж таки потрапляе в простір між кабіною та фургоном (рис. 12), що спричинює завихрення та акустичний шум позаду кабіни (рис. 13).

Значення коефіцієнта лобового опору $C_{x}$, розрахованого за умови руху автомобіля 3 увігнутим спойлером, становить

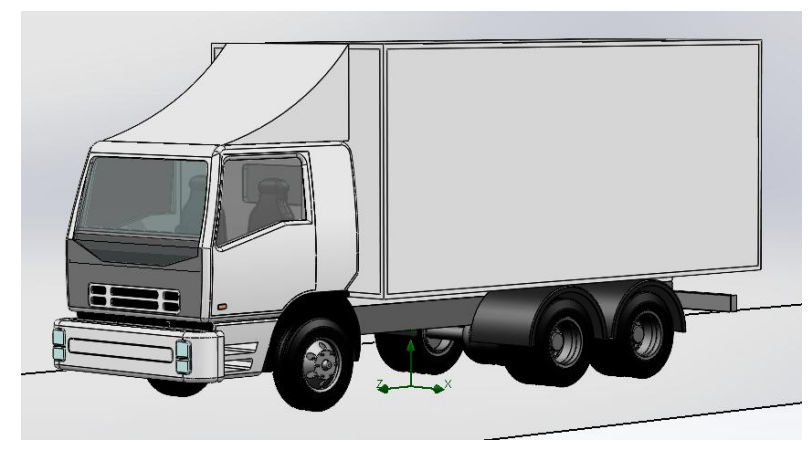

Рис. 10. Вантажний автомобіль з увігнутим спойлером

Fig. 10. Truck with concave spoiler

$$
C_{x}=\frac{2 \cdot 2392}{1,21 \cdot 9,07 \cdot 25^{2}}=0,7 \text {. }
$$

Результати моделювання руху автомобіля 3 плоским спойлером. Плоский спойлер змодельовано у формі прямокутного щита, ширина якого рівна ширині кабіни автомобіля, як здебільшого й трапляється на практиці за умови використання плоских спойлерів-щитів. Встановлено значення сили лобового опору $F_{\mathrm{s}}=2317 \mathrm{H}$ (рис. 14).

Використання плоского спойлера покращує аеродинамічні характеристики автомобіля, однак теж має суттєві недоліки, а саме: наявність на передній стінці кузова-фургона зони високого опору тиску (рис. 15), утворення зони акустичного шуму за кабіною водія (рис. 16), а також наявність зони сильного завихрення над кабіною (рис. 17), що спричинено самою конструкцією спойлера, в якого відсутні бічні стінки.

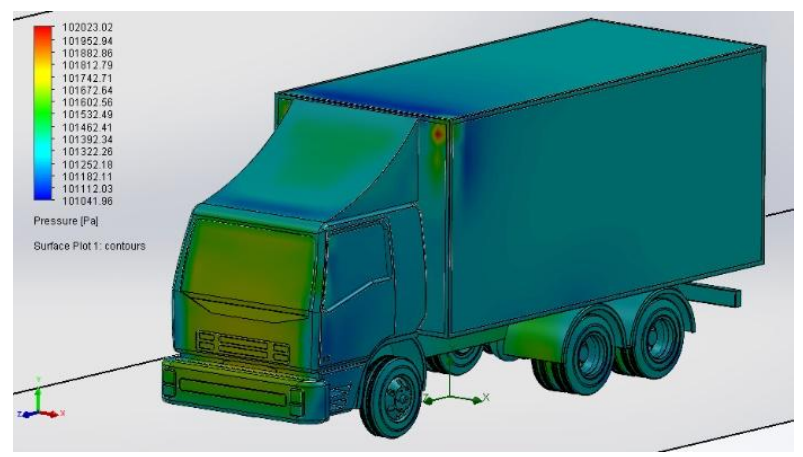

Рис. 11. Діаграма опору тиску

Fig. 11. Pressure resistance level plot

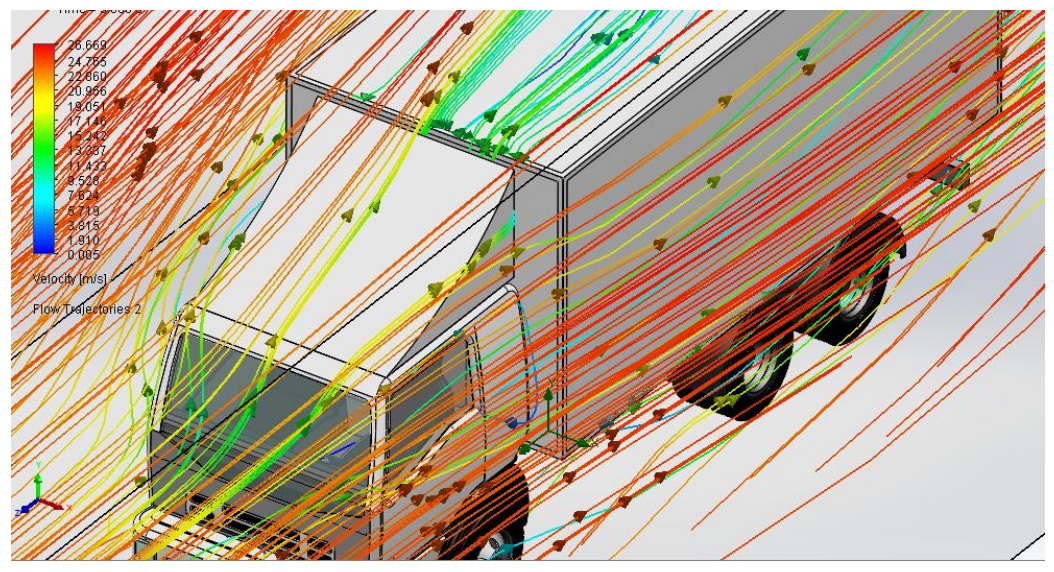

Рис. 12. Діаграма швидкостей руху повітря Fig. 12. Velocity plot

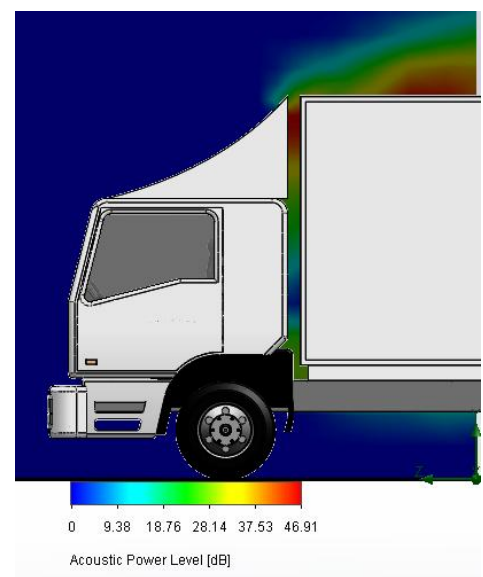

Рис. 13. Діаграма акустичного шуму

Fig. 13. Acoustic level plot 


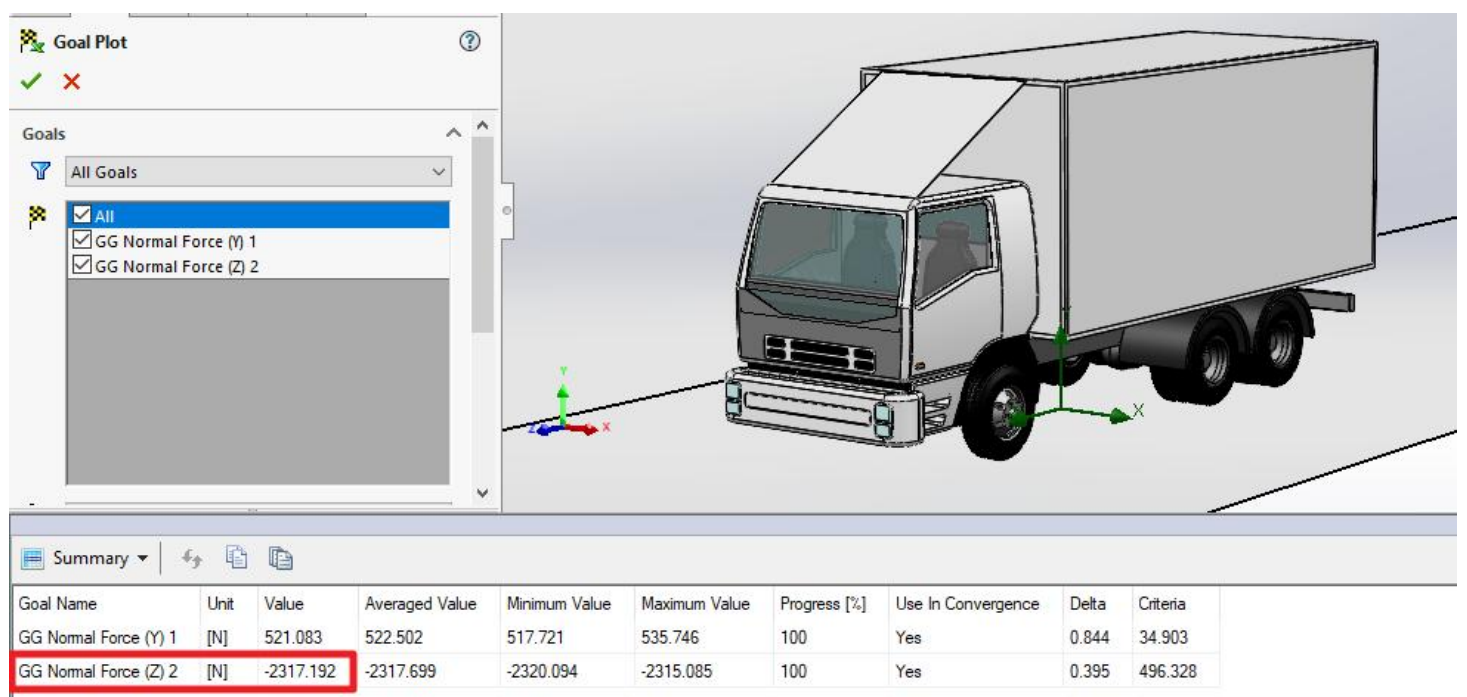

Рис. 14. Визначення сили лобового опору вантажного автомобіля з плоским спойлером прямокутної форми Fig. 14. Determination of the drag force of a truck with a flat rectangular spoiler

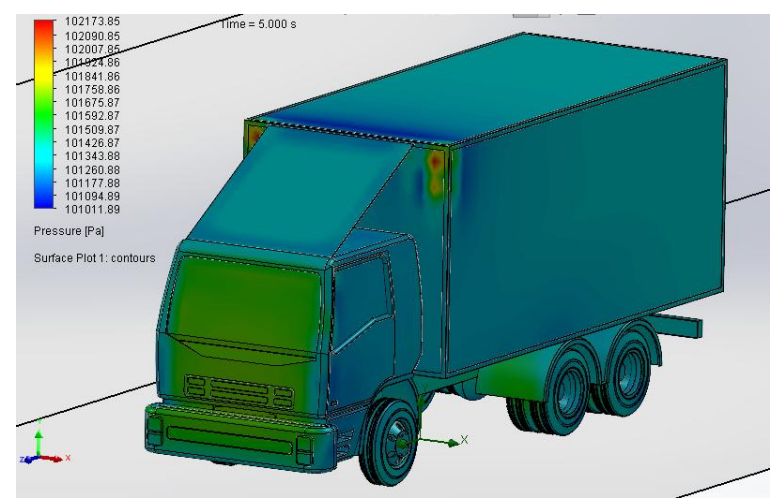

Рис. 15. Діаграма опору тиску

Fig. 15. Pressure resistance level plot

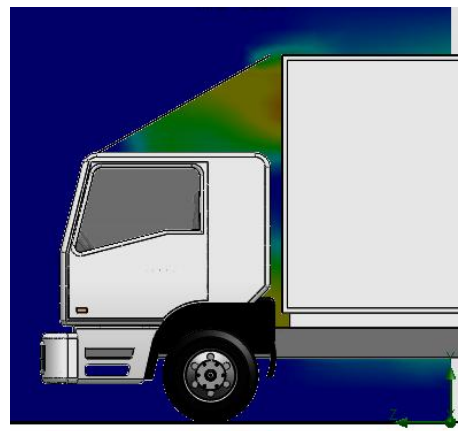

$\begin{array}{llllll}0 & 8.41 & 16.81 & 25.22 & 33.63 & 42.03\end{array}$

Acoustic Power Level [dB]

Рис. 16. Діаграма акустичного шуму Fig. 16. Acoustic level plot

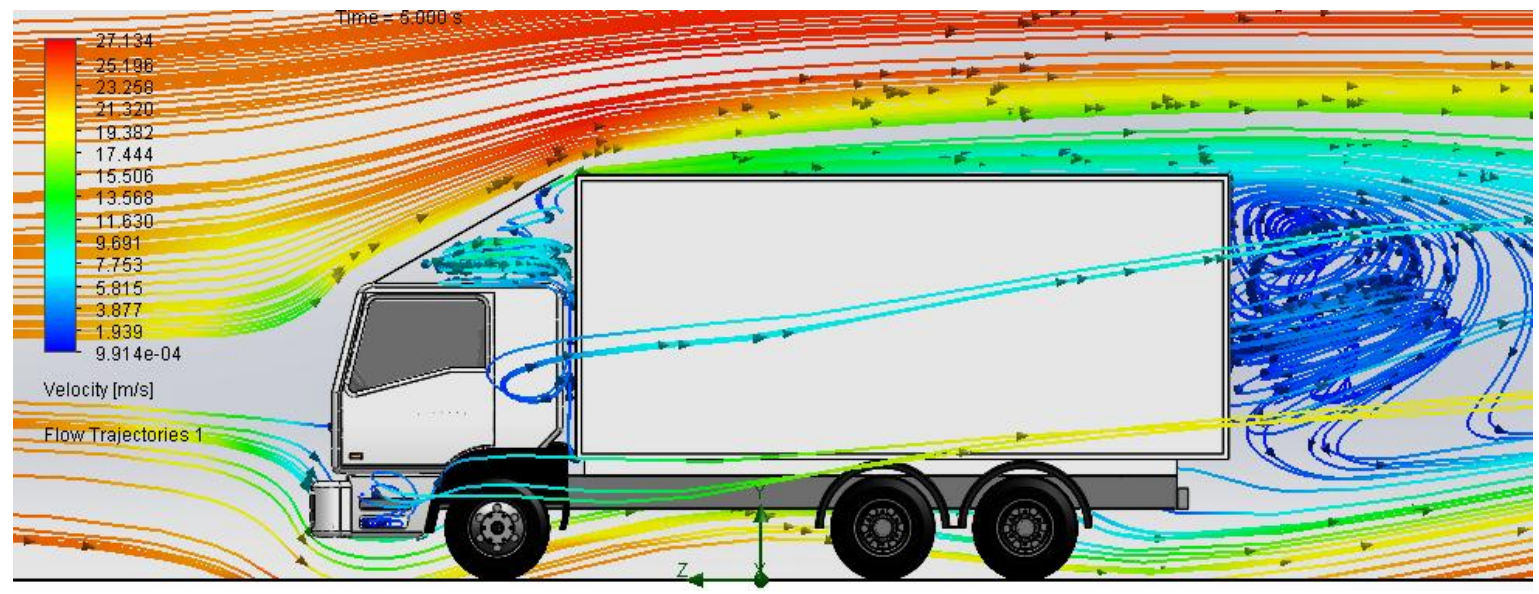

Рис. 17. Діаграма швидкостей руху повітря

Fig. 17. Velocity plot 
Крім наведених експлуатаційних недоліків використання плоского спойлера у формі прямокутного щита, використання такого спойлера не додає автомобілю естетичної привабливості.

Значення коефіцієнта лобового опору $C_{x}$ за умови використання плоского спойлера прямокутної форми становить

$$
C_{x}=\frac{2 \cdot 2317}{1,21 \cdot 9,07 \cdot 25^{2}}=0,68 \text {. }
$$

Результати моделювання руху автомобіля з випуклим спойлером. Випуклий спойлер має параболічну випуклу форму (рис. 18). Його ширина дорівнює ширині кабіни. Бічні стінки $\epsilon$ прямими та зменшують імовірність потрапляння потоків повітря зі сторін у простір між кабіною водія та кузовом-фургоном.

Значення сили лобового опору $F_{\mathrm{I}}=2271 \mathrm{H}$ (див. рис. 18).

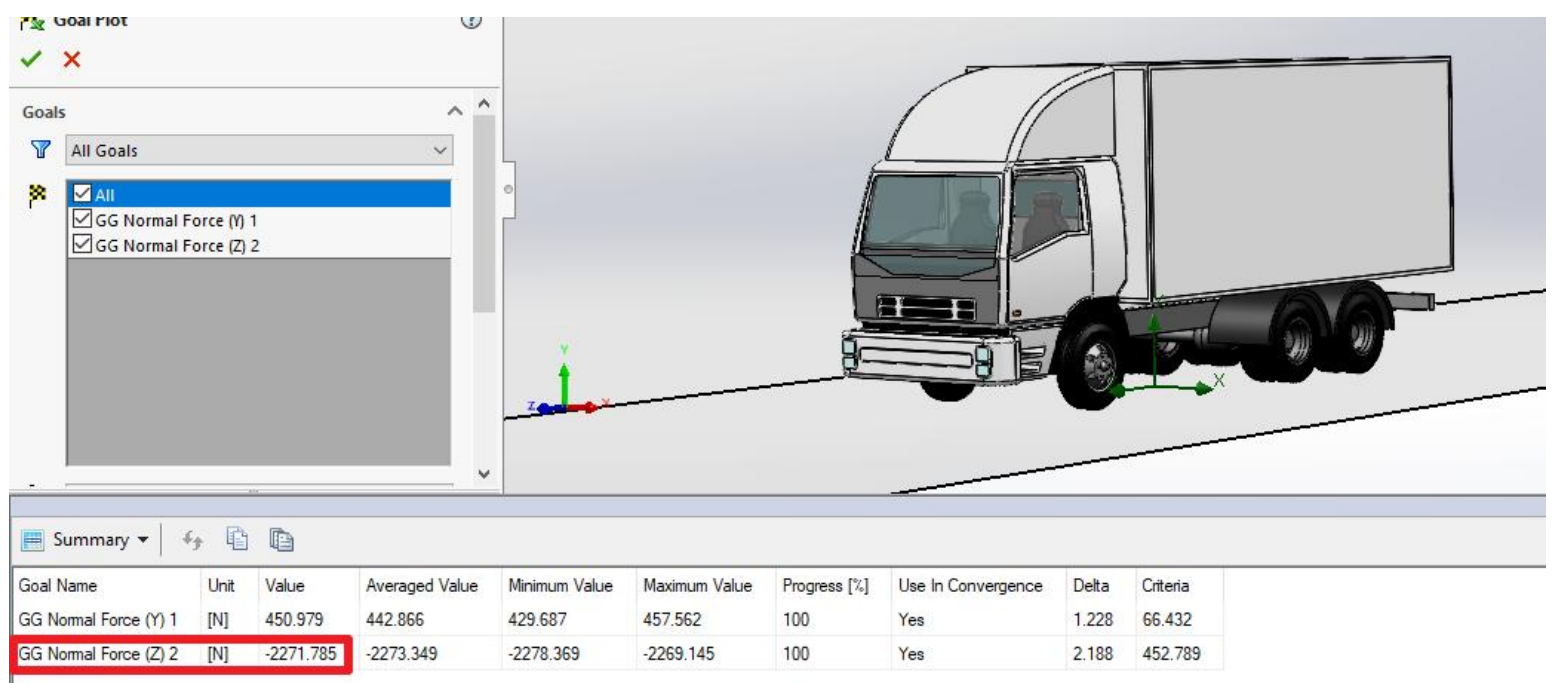

Рис. 18. Визначення сили лобового опору вантажного автомобіля з випуклим спойлером

Fig. 18. Determination of the drag force of the truck with a convex spoiler

Порівняно $з$ попередніми варіантами використання увігнутого та плоского спойлера, випуклий спойлер забезпечує кращі результати аеродинаміки автомобіля, зокрема траєкторії руху набігаючого повітря більше відповідають ламінарному режиму. Однак, як видно з рис. 19-21, випуклий спойлер не усуває повністю зони підвищеного

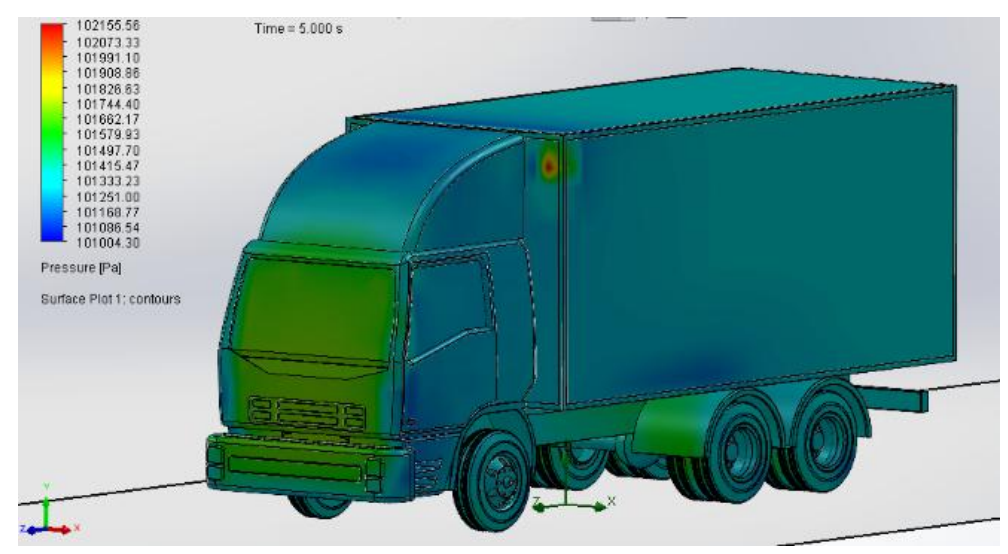

Рис. 19. Діаграма опору тиску

Fig. 19. Pressure resistance level plot опору тиску на передній стінці кузова-фургона та зони акустичних шумів між кабіною та фургоном.

Така форма спойлера дає змогу зменшити коефіцієнт лобового опору $C_{x}$, значення якого становить

$$
C_{x}=\frac{2 \cdot 2271}{1,21 \cdot 9,07 \cdot 25^{2}}=0,66
$$

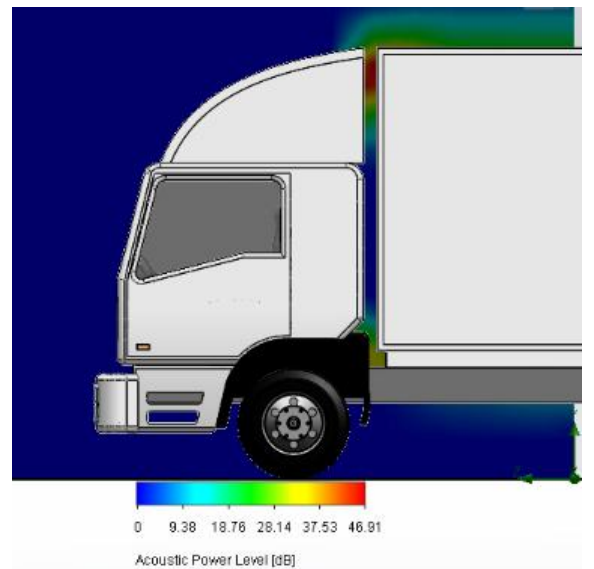

Рис. 20. Діаграма акустичного шуму Fig. 20. Acoustic level plot 


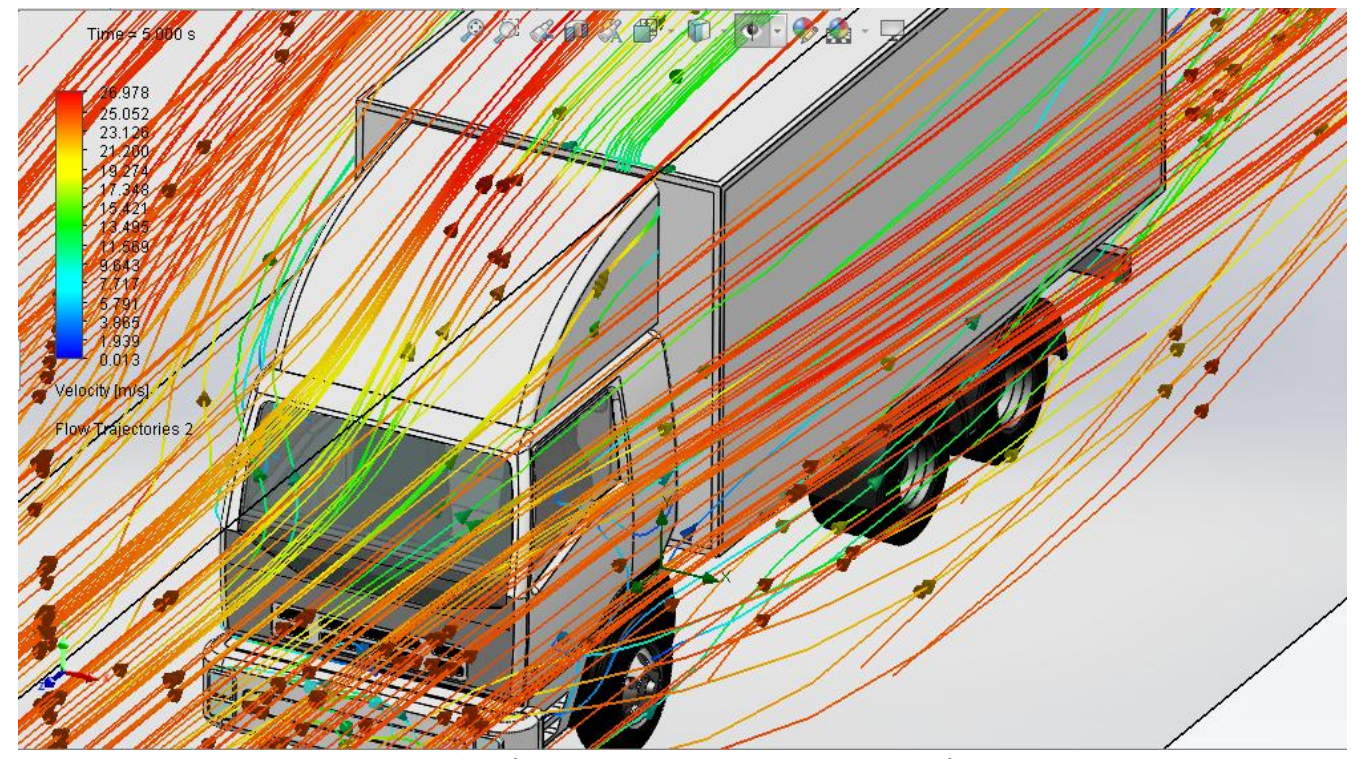

Рис. 21. Діаграма швидкостей руху повітря

Fig. 21. Velocity plot

Аналіз показників аеродинаміки автомобіля за умови використання спойлерів різних типових геометричних форм вказує на необхідність удосконалення геометричної форми спойлера виходячи 3 результатів проведення аеродинамічного моделювання руху автомобіля.

\section{Результати моделювання руху авто-} мобіля зі спойлером складної геометричної форми. Під час проєктування спойлера необхідно змоделювати таку його геометричну форму, щоб поверхні спойлера забезпечували спрямування набігаючого повітряного потоку, який сходить 3 лобової поверхні кабіни автомобіля, над кабіною та над верхньою стінкою фургона, а також на бічні поверхні фургона, забезпечивши траєкторії руху повітря 3 мінімізацією сили опору поверхонь автомобіля та можливих завихрень. Для створення такої форми використано метод геометричного моделювання, який не забезпечується моделюванням конструктивами, тобто використанням стандартних геометричних тіл (паралелепіпед, сфера, конус, тор тощо), над якими виконуються геометричні операції моделювання - об'єднання, видалення, перетину.

Виходячи 3 геометричних параметрів автомобіля, геометрична форма спойлера одержана методом об'єктно-орієнтованого моделювання, тобто на основі аналізу траєкторій руху потоків повітря, що набігають на автомобіль, та наближеного повторення формою поверхонь спойлера в різних перерізах траєкторій руху повітря, яке обтікає кузов автомобіля. У трьох площинах проєкцій побудовано сплайни, одні з яких використано як контури, а інші - як напрямні для моделювання геометричної форми спойлера. Поперечний переріз спойлера - параболічної форми; ширина його нижньої частини дорівнює ширині кабіни автомобіля, а верхньої - ширині кузовафургона (рис. 22).

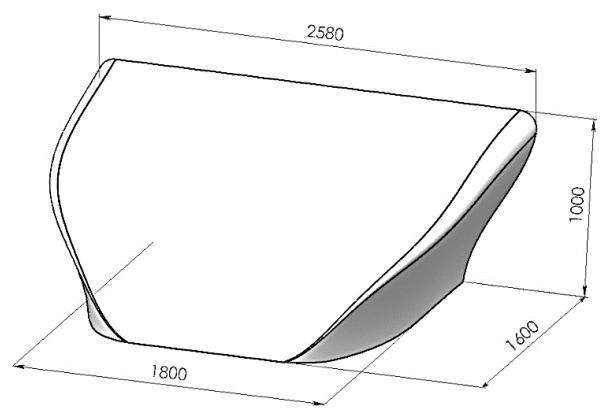

Рис. 22. Спойлер об'ємний

Fig. 22. Volume spoiler

Завдяки такій конфігурації спойлера на передній стінці фургона усувається зона підвищеного тиску опору, оскільки проєкція спойлера на площину, перпендикулярну до центральної поздовжньої площини автомобіля, повністю перекриває зону утворення підвищеного тиску опору у верхній частині передньої стінки фургона. Перехід від нижньої частини спойлера до верхньої виконано фігурними хвилеподібними боковими поверхнями (рис. 23), які плавно відводять частину потоку повітря на бічні поверхні кузовафургона. А спряження між параболічною поверхнею верхньої частини спойлера і боковими поверхнями виконано у формі плавного заокруглення змінного радіуса (рис. 24). 


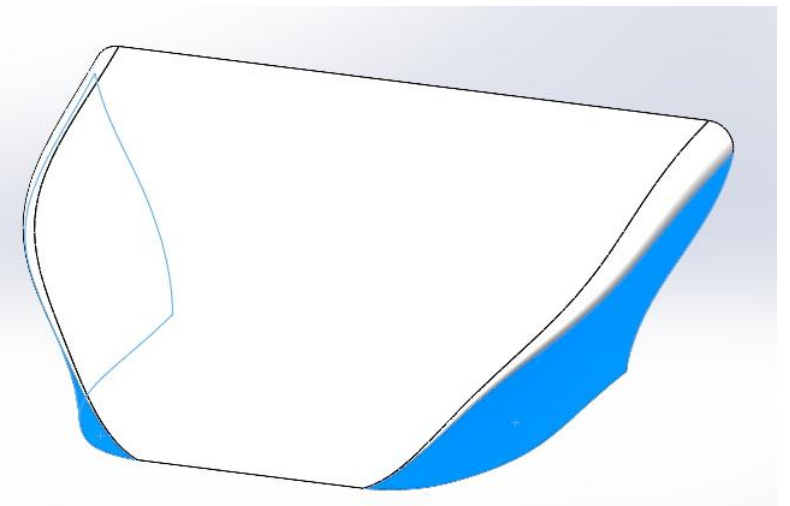

Рис. 23. Бокові поверхні спойлера Fig. 23. Side surfaces of the spoiler

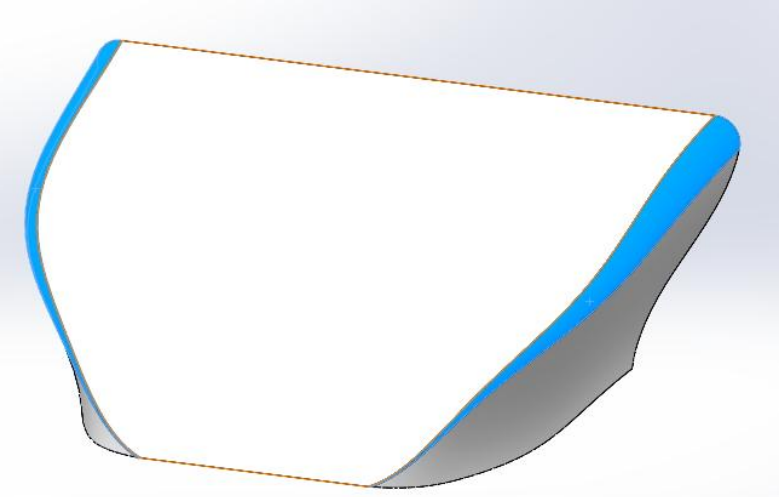

Рис. 24. Спряження поверхонь спойлера Fig. 24. Conjugation of spoiler surfaces

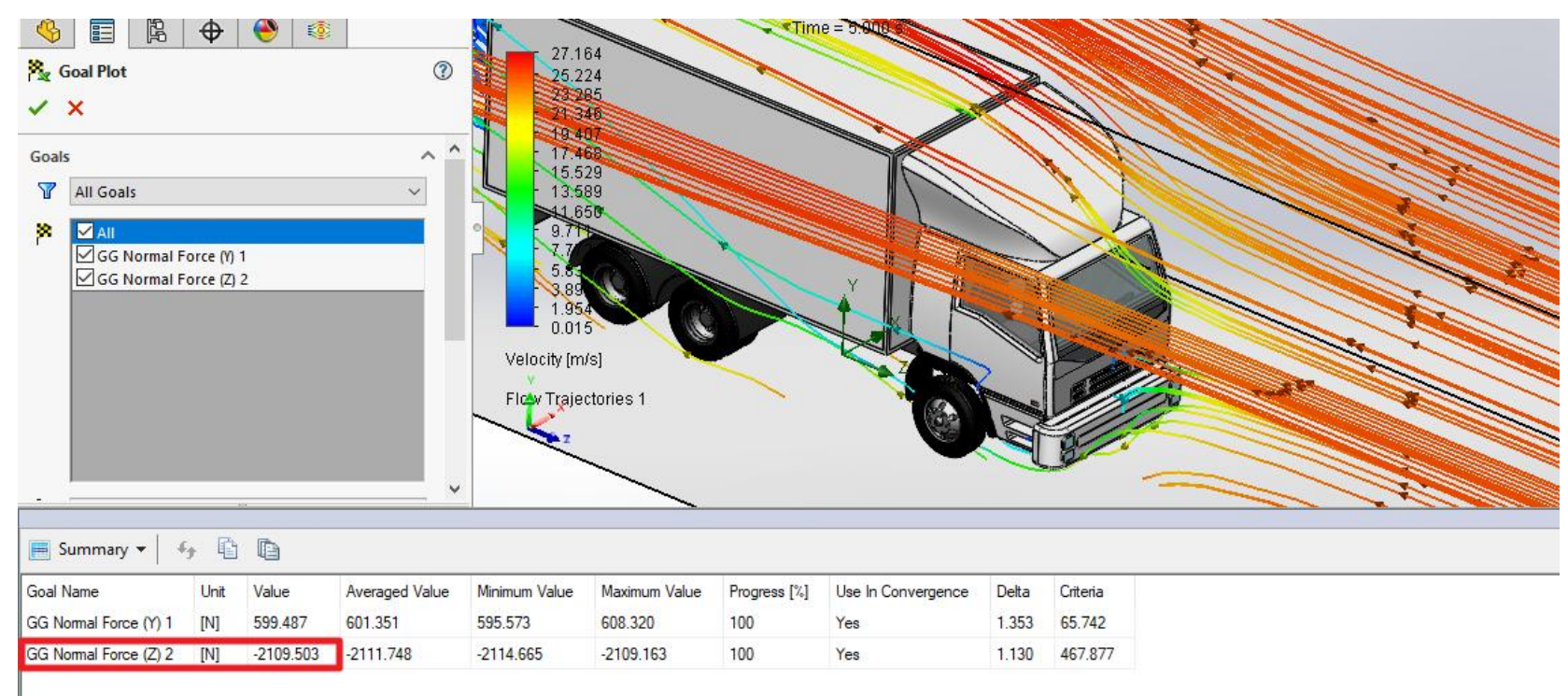

Рис. 25. Визначення сили лобового опору вантажного автомобіля з об’ємним спойлером запропонованої форми

Fig. 25. Determination of the drag force of a truck with a three-dimensional spoiler of the proposed shape

За результатами аеродинамічного моделювання за умови використання спойлера запропонованої геометричної форми сила лобового опору становить $F_{\mathrm{л}}=2110 \mathrm{H}$ (див. рис. 25 ).

Завдяки застосуванню об'єктноорієнтованого методу моделювання вдалося створити таку форму спойлера, яка дасть змогу повністю усунути зони підвищеного тиску опору на поверхні передньої стінки фургона (рис. 26); за рахунок хвилеподібної форми бокових стінок спойлера потоки повітря плавно й без завихрень відводяться на бокові поверхні фургона. Також усунено зону утворення акустичних шумів над кабіною та за нею (рис. 27), оскільки потік повітря не потрапляє в простір між кабіною і фургоном або під спойлер, а максимально спрямовується паралельно до повздовжньої площини автомобіля, плавно обтікаючи його поверхні (рис. 28).

Значення коефіцієнта лобового опору $C_{x}$ за умови використання запропонованого спойлера становить

$$
C_{x}=\frac{2 \cdot 2110}{1,21 \cdot 9,07 \cdot 25^{2}}=0,62
$$

Як видно 3 результатів, запропонований варіант геометричної форми спойлера забезпечує мінімальні значення коефіцієнта лобового опору $C_{x}$ порівняно зі спойлерами плоскої прямокутної форми, об'ємного увігнутого циліндричної форми та об’ємного випуклого параболічної форми. 


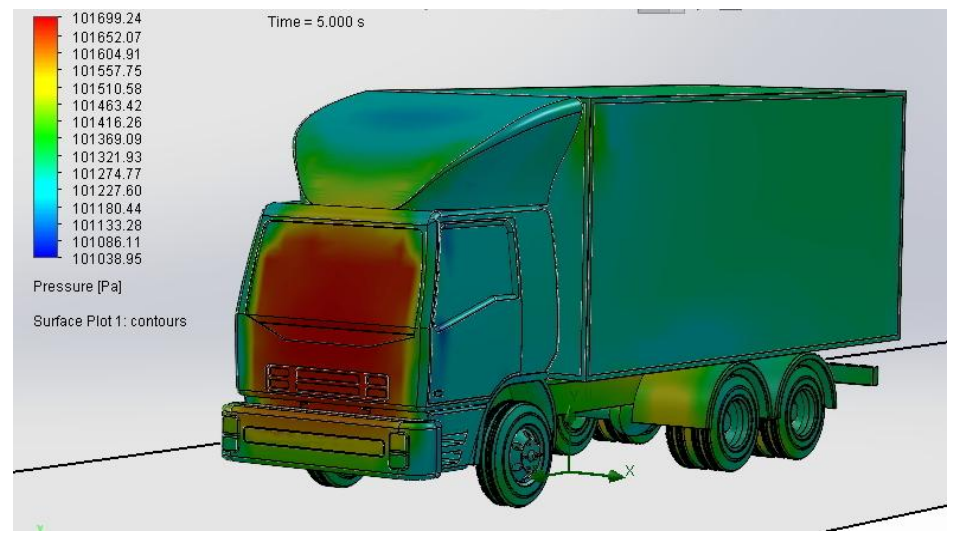

Рис. 26. Діаграма опору тиску Fig. 26. Pressure resistance level plot

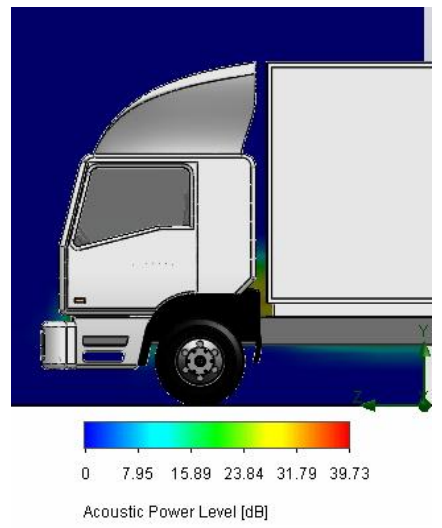

Рис. 27. Діаграма акустичного шуму

Fig. 27. Acoustic level plot
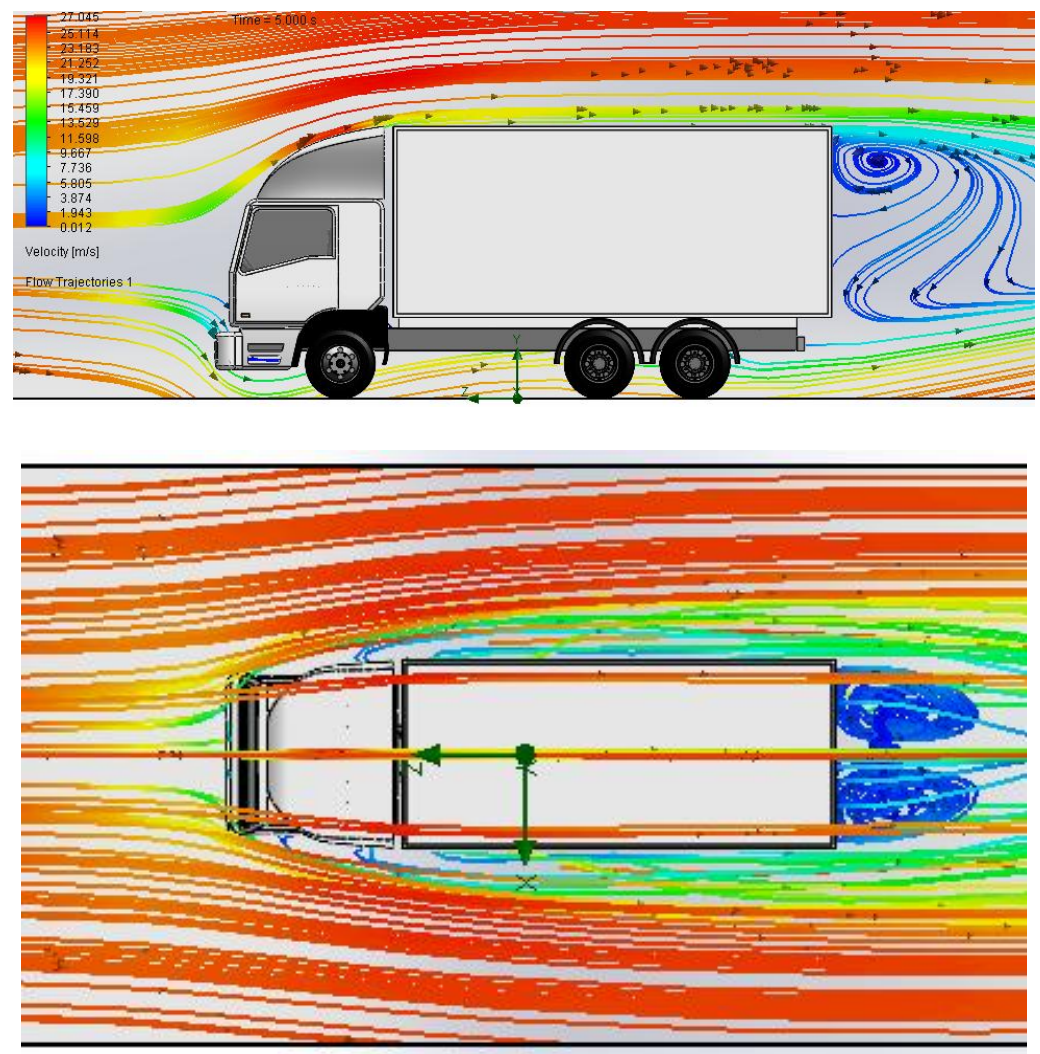

Рис. 28. Діаграма швидкостей руху повітря

Fig. 28. Velocity plot

Аналіз результатів досліджень. Порівняльну характеристику результатів використання спойлерів різної геометричної форми та запропонованої форми спойлера, а також вплив на аеродинамічну характеристику вантажного автомобіля наведено на діаграмах (рис. 29-31).
Як видно 3 діаграм, використання запропонованого варіанта спойлера складної геометричної форми, змодельованої методом об'єктно-орієнтованого моделювання, за результатами аеродинамічних досліджень забезпечує найкращі результати, зокрема дозволяє зменшити коефіцієнт лобового опору руху автомобіля на $17 \%$. 


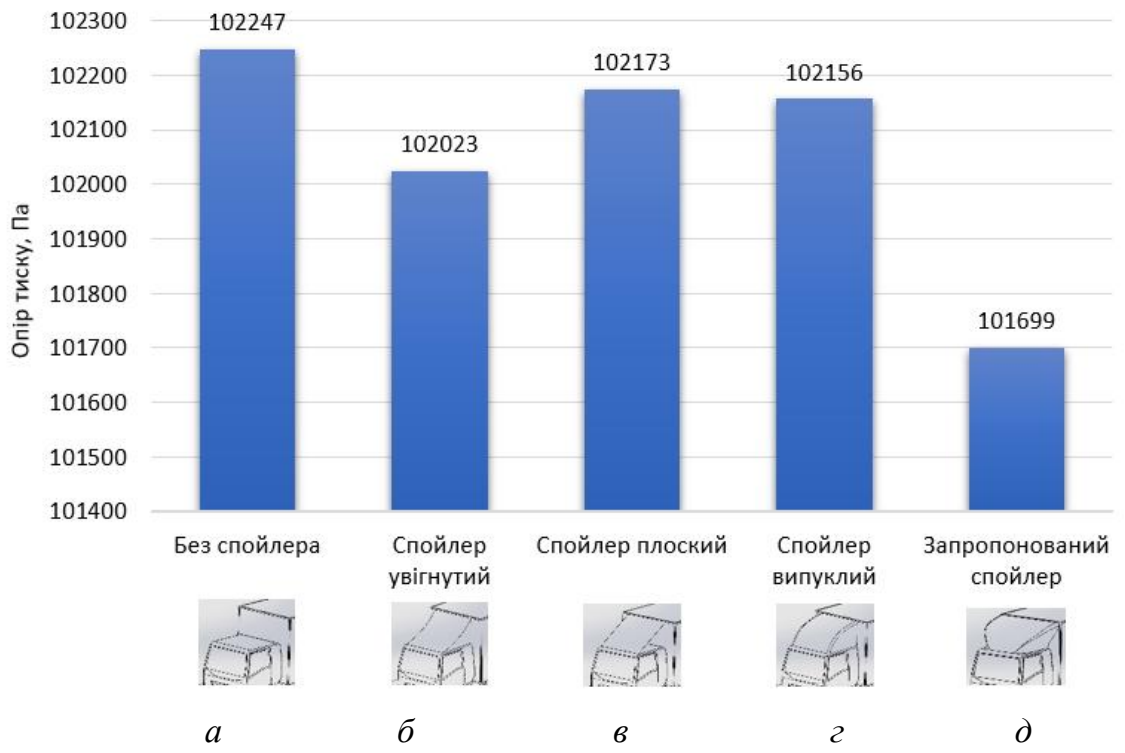

Рис. 29. Діаграма опору тиску на поверхнях автомобіля з використанням спойлерів різних геометричних форм: $a$ - автомобіль без спойлера; $\sigma$ - з увігнутим спойлером циліндричної форми; $8-3$ плоским спойлером прямокутної форми; 2 - зі спойлером параболічної форми; $\partial$ - із запропонованим спойлером складної геометричної форми

Fig. 29. Diagram of pressure resistance on the surfaces of a car using spoilers of different geometric shapes: $a$ - car without spoiler; $\sigma$ - with a concave cylindrical spoiler; $b$ - with a flat spoiler of rectangular shape; 2 - with a parabolic spoiler; $\partial-$ with the proposed spoiler of complex geometric shape

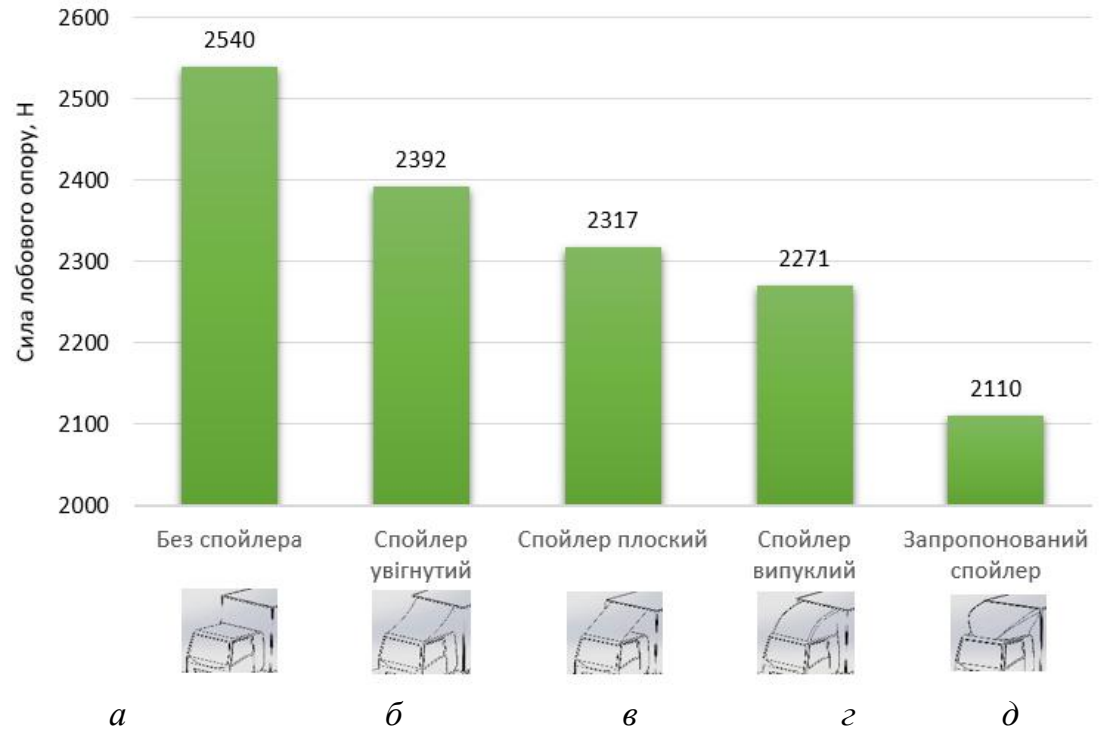

Рис. 30. Діаграма сили лобового опору автомобіля з використанням спойлерів різних геометричних форм: $a$ - автомобіль без спойлера; $\sigma$ - з увігнутим спойлером циліндричної форми; $b-3$ плоским спойлером прямокутної форми; 2 - зі спойлером параболічної форми; $\partial$ - із запропонованим спойлером складної геометричної форми

Fig. 30. Diagram of the drag force of a car using spoilers of different geometric shapes: $a$ - car without spoiler; $\sigma-$ with a concave cylindrical spoiler; 6 - with a flat rectangular spoiler; 2 - with a parabolic spoiler; $\partial-$ with the proposed spoiler of complex geometric shape 


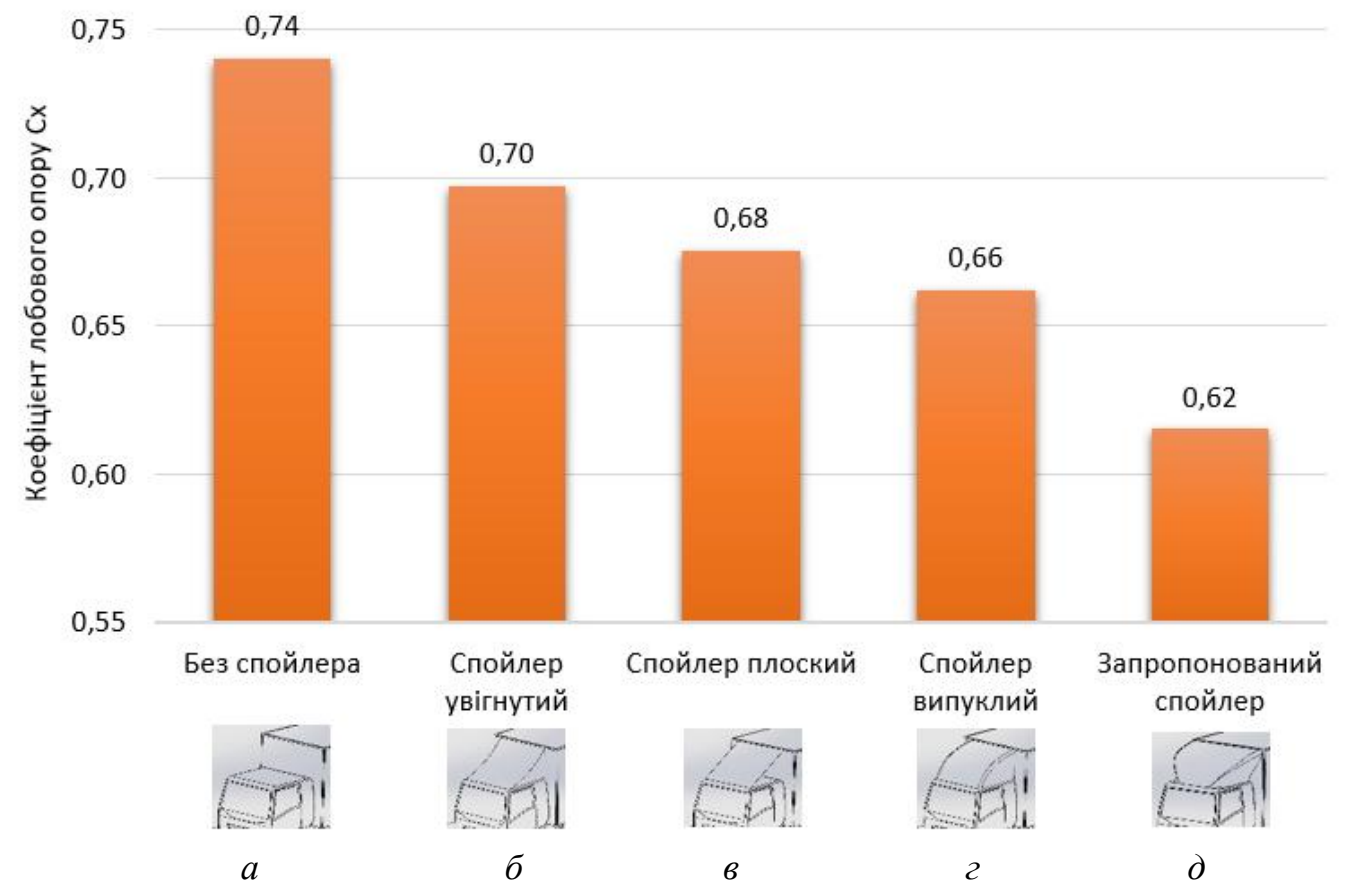

Рис. 31. Діаграма коефіцієнта лобового опору автомобіля з використанням спойлерів різних геометричних форм: $a$ - автомобіль без спойлера; $\sigma$ - з увігнутим спойлером циліндричної форми; $6-3$ плоским спойлером прямокутної форми; г - зі спойлером параболічної форми; $\partial$ - із запропонованим спойлером складної геометричної форми

Fig. 31. Diagram of the coefficient of drag of a car using spoilers of different geometric shapes: $a$ - car without spoiler; $\sigma$ - with a concave cylindrical spoiler; 6 - with a flat rectangular spoiler; 2 - with a parabolic spoiler; $\partial-$ with the proposed spoiler of complex geometric shape

\section{Висновки}

1. В ефективності використання обтічних елементів вантажних автомобілів важливу роль відіграє не лише наявність спойлера-обтічника кабіни, а й його геометрична форма. Під час виготовлення спойлерів на практиці не приділяють значної уваги обгрунтуванню геометричної форми спойлерів. Геометричну форму генерують, враховуючи габаритні розміри конкретного автомобіля, для якого виготовляється спойлер, а також виходячи 3 естетичних міркувань. У разі виготовлення універсальних спойлерів ефективність їх використання ще нижча, оскільки не враховано компонувальні конфігурації автомобілів, наприклад, різницю висот та ширини кабіни й фургона, кут нахилу вітрового скла, інші особливості конструкції конкретної марки автомобіля, на якому використовуватиметься спойлер.

2. Враховуючи те, що під час моделювання геометричної форми спойлера дослідження в аеродинамічній трубі $є$ економічно недоцільним, то використання сучасного спеціалізованого програмного середовища, яке б поєднувало можли- вість геометричного моделювання та аеродинамічних досліджень запроєктованої моделі, дозволяє уникнути помилок ще на етапі проєктування. Таку можливість, зокрема, дає пакет програмних продуктів SolidWorks.

3. Створення необхідної геометричної форми спойлера за допомогою моделювання конструктивами, над якими виконуються геометричні операції моделювання, не забезпечує хороших результатів. Ефективнішим методом моделювання геометричної форми спойлера є метод об'єктноорієнтованого моделювання, який полягає в тому, що форма спойлера повторює траєкторії руху повітря, яке обтікає кузов автомобіля в різних перерізах.

4. За критерій ефективності створення оптимальної геометричної форми спойлера доцільно взяти коефіцієнт лобового опору автомобіля $C x$, визначеного на підставі аеродинамічного дослідження, наприклад, у середовищі SolidWorks Flow Simulation.

5. Найкращі результати забезпечує використання спойлера складної геометричної форми, 
геометричне моделювання якого виконано методом об'єктно-орієнтованого моделювання за результатами аеродинамічного дослідження. Так, результатами дослідження встановлено, що спойлер увігнутий циліндричної форми дозволяє зменшити коефіцієнт лобового опору автомобіля на $6 \%(C x=0,7)$ порівняно 3 автомобілем без спойлера $(C x=0,74)$. Плоский спойлер прямокутної форми зменшує коефіцієнт лобового опору на $9 \%$ $(C x=0,68)$; спойлер випуклий параболічної форми - на $11 \%(C x=0,66)$; запропонований спойлер складної геометричної форми - на $17 \%(C x=0,62)$. Крім того, запропонований спойлер дозволяє усунути зовнішні акустичні шуми (44,9 дБ), які виникали в зоні кабіни водія в результаті завихрень і турбулентності повітряних потоків.

6. Використаний підхід до моделювання геометричної форми спойлера кабіни вантажного автомобіля дає змогу проєктувати форми спойлерів різних габаритних розмірів та компонувань транспортних засобів, 3 достатньою точністю визначити ефективність його експлуатації ще на етапі проєктування.

\section{Бібліографічний список}

1. Алямовский А. А. Инженерные расчеты в SolidWorks Simulation. Москва: ДМК Пресс, 2010. 464 с.

2. Алямовский А. А. SolidWorks Simulation. Инженерный анализ для профессионалов: задачи, методы, рекомендации. Москва: ДМК Пресс, 2015. 562 с.

3. Алямовский А. А. SolidWorks Simulation. Как решать практические задачи. Санкт-Петербург: БХВ-Петербург, 2012. 448 с.

4. Бернацкий В. В., Степанов И. С., Кондрашов В. Н. Аэродинамика автомобиля. Методы испытаний: учеб. пособие. Москва: Ун-т машиностроения (МАМИ), 2013. 153 c.
5. Дьячков Ю. А. САПР в автомобиле- и тракторостроении: лабораторный практикум. Пенза: ПГУ, 2012. $164 \mathrm{c.}$

6. Евграфов А. Н. Аэродинамика автомобиля: учеб. пособие. Москва: МГИУ, 2010. 356 с.

7. Евграфов А. Н., Есеновский Ю. К., Рыбин Е. Л. Совершенствование аэродинамики - резерв экономии топлива. Известия МГИУ. 2011. № 3(23). C. 22-24.

8. Пилипенко О. М., Батраченко О. В., Литовченко I. М. Зменшення аеродинамічного опору кабіни вантажного автомобіля. Вісник Хмельницького національного університету. 2018. № 3 (261). С. 69-73.

9. Пустюльга С. І., Самостян В. Р. Машинобудівне креслення: навч. посіб. Луцьк: Вежа, 2015. 275 с.

10. Пустюльга С. І., Самостян В. Р., Клак Ю. В. Інженерна графіка в SolidWorks: навч. посіб. Луцьк: Вежа, 2018. 174 c.

11. Филькин Н. М., Шаихов Р. Ф., Буянов И. П. Теория транспортных и транспортно-технологических машин: учеб. пособие. Пермь: ФГБОУ ВО Пермская ГСХА, 2016. $230 \mathrm{c.}$

12. Цонинець Р. М. Аналіз геометричних форм спойлерів кабін вантажних автомобілів. Студентська молодь і науковий прогрес в АПК: тези доп. Міжнар. студ. наук. форуму, 22-24 верес. 2020 р. Львів, 2020. C. 389.

13. Шпак Я. В., Ланець О. С., Гурський В. М. Трьохмірне моделювання у програмі SolidWorks: методичні вказівки та інструкція до виконання індивідуальних контрольних робіт. Львів: Рукопис, 2011.30 c.

14. Belzile M. Review of Aerodynamic Drag Reduction Devices for Heavy Trucks and Buses: Technical Report. Канада, 2012. URL: www.tc.gc.ca (Last accessed: 19.09.2021).

15. SolidWorks. Компьютерное моделирование в инженерной практике / А. А. Алямовский и др. СанктПетербург: БХВ-Петербург, 2005. 800 с.

Стаття надійшла 22.09.2021 